\title{
ANALYSIS AND EVALUATION OF THE CHOSEN ASPECTS OF THE ANTI-DOPING IN SPORT AS A ROLE OF AUTHORITIES OF THE COUNTRY IN ORDER TO ASSURE SAFETY IN SPORT
}

\begin{abstract}
The article analyzes and evaluates the legal and organizational regulations adopted on the basis of worldwide standards set by the institutions specialized in counteracting the phenomenon of doping in sport. The biggest attention was placed on the Polish Anti-Doping Agency (POLADA), established in 2017 under the Law against doping in sports whose complex rules of operation are defined in several separate legal acts. The reflections were supported by examples of the most infamous doping scandals of recent times, both in Poland and international.

The author finds that the current legal regulations, as well as their practical application, allow effective counteraction of individuals and entities using or spreading substances and methods prohibited by the law. Legal regulations and as a consequence the activities of institutions such as the Polish Anti-Doping Agency must be a subject to the continuous evaluation in order to be able to respond to the latest attempts to use banned doping in sport, because it has a direct impact on ensuring broadly understood safety and security in sports.

In addition, the author indicates that one of the best methods of combating doping is to highlight its possible negative effects. Therefore, further educational programs should be initiated and propagated in the society, followed by spreading information matter of doping, because the phenomenon of using prohibited substances and methods by professional athletes is in contrary to the fundamental principle that should lead sports competition fair play. Additional severe consequences that might be revealed in the future, may also be serious health problems for people using doping during their careers.
\end{abstract}

Keywords: doping in sports, Polish Anti-Doping Agency, prohibited substances, banned methods.

\section{INTRODUCTION}

Professional and uncompromising combat against the phenomenon of usage of the banned doping is one of the most important and at the same time the most challenging

\footnotetext{
${ }^{1}$ Patryk Masłowski, MSc, Department of Law and Administration, The Faculty of Management Rzeszów University of Technology, 2 Akademicka Street, Rzeszów 35-959, room 209 Arcus; e-mail: patrykmaslowski@prz.edu.pl. ORCID: 0000-0002-6087-7248.

Mgr Patryk Masłowski, Katedra Prawa i Administracji na Wydziale Zarządzania Politechniki Rzeszowskiej im. I. Łukasiewicza, ul. Akademicka 2, 35-959 Rzeszów, bud. Arcus, pokój nr 209; e-mail: patrykmaslowski@prz.edu.pl. ORCID: 0000-0002-6087-7248.
} 
everyday life tasks that rest on public institutions, required to play as a guarantee of the safety in sports. Doping understood as a form of dishonest practice used by the sportsmen in order to gain results exceeding their natural abilities is commonly seen not only among professionals but also among amateurs. The beginning of the era of the modern doping falls to 20th century when players who practice sports involving long-term physical activities commenced to reach for a substances which allow them to get results overcoming their abilities. Among the most popular drugs at the time, one can find caffeine, nitroglycerine or opium ${ }^{2}$. Doping was always linked with excessive desire of the victory and also arising pressure for breaking consecutive achievements or gaining another records ${ }^{3}$. The result of such a practice is constantly growing financial capital invested in sport at the highest level. Sportsmen become stars, celebrities, authorities for public opinion or even fashion icons setting the latest trends. It is the desire to stay on the top that results in reaching for the substances banned in their regular professions. By noticing the problem of the existence of doping in sports, organizations at both international and national level are equipped with a number of law regulations and obligations to fight against doping at multiple levels. In order to achieve that goal, polish legislator appointed, pursuant to Law of $21^{\text {st }}$ April 2017 against doping control, new legal subject who is believed to counteract doping in sport in an effective and transparent manner, not only following international standards but even setting the new ones. Such a legal subject is Polish Anti-doping Agency located in Warsaw. The nature of its activities is not only an action in cases when prohibited practices have already took place but it has also preventive character, represented by organizing multiple programs and trainings dedicated to sportsman, coaches or sport activists. Another goal is to prevent from the negative consequences possible whenever sportsman is deemed using prohibited performance-enhancing drugs or methods. Besides such negative consequences of being found positive to use doping such as dishonesty in the sport competition, and in consequence presenting lack of the respect for the noble ides of the physical education, not to forget about the effects on a human body such as risk of health problems followed by the various possible complications, to finish with the scandals, well attended by the media that are visibly interested in sports and any related topics and that presents the information about popular, widely known figures from sports ${ }^{4}$ world picturing doping as a scandal and sensation $^{5}$. Such an approach has negative impact on the perception of sport among supporters and potential sponsors.

The concept of the prohibited substance and prohibited method has been briefly described in the International Convention against Doping in Sport ${ }^{6}$. According to the Article 2, paragraph 18 and paragraph 19, they are defined as any substance or method which is declared as prohibited on the List of Prohibited Substances and Methods presented in Annex

${ }^{2}$ M. Zawartka, Zagrożenia dla bezpieczeństwa w sporcie [in:] M. Bednarczyk, K. Nessel, Przedsiębiorczość w sporcie zasady i praktyka, Warsaw 2016, p. 218.

3 A. Leszczyńska, Szprycujący się koksiarze przytapani na dopingu. Obraz zjawiska dopingu w sporcie w polskiej prasie na przyktadzie tekstów z ,Gazety Wyborczej” i „Przegladu Sportowego” [in:] M. Jarosz, P. Drzewiecki, P. Płatek, Sport w mediach, Warsaw 2013, p. 324.

4 The Law of 21 st April 2017 against Doping (Journal of Laws 2017, item 1051).

5 M. Pasik, D. Kwiatkowska, A. Pokrywka, Doping w sporcie i doping oczami mediów - próba charakterystyki zjawiska [in:] M. Jarosz, P. Drzewiecki, P. Płatek, Sport w mediach..., p. 406.

${ }^{6}$ International Convention Against Doping in Sports dated 19th October 2005 (Journal of Laws of 2007, item 999, Journal of Laws of 2013, item 1243, Journal of Laws of 2014, item 343, Journal of Laws of 2016, item 79 and 332, Journal of Laws of 2017 item 263.). 
1 to the Convention. It is worth mentioning that due to the fact that doping in sport is dynamically evolving, legislator used general terms in order to keep general character and ensure ability to update them as required by the subjects responsible for anti-doping measures. Current (as of 2018) Annex $n^{\circ} 1$ to the International Convention against Doping in Sport enlist six groups of substances described as prohibited and three methods identified as banned ${ }^{7}$. These specifications concern substances and methods prohibited to use not only during but also outside of the competitions. Furthermore, the catalogue has been extended to include four further groups of prohibited substances that will be tested during the competition only. At this point, it is worth mentioning that according to the polish law, timeframe for the competition starts 12 hours before the competition meaning single race, game or sport event, until it is finished, unless the provision set by the respective sports organization or organizer of the competition requires otherwise, including the timeframe for the anti-doping regulations related to the event ${ }^{8}$.

\section{CONTEMPORARY VIEW OF THE DOPING IN SPORTS}

Definition of the doping in sport has evolved throughout the years by adjusting its content to the needs required by the current state. Number of times it could have been observed that sportsmen using various substances enhancing their motoric or mental abilities by benefiting from the knowledge of the specialists in the domain of chemistry, biology were able to hide this fact from the knowledge of institutions responsible for the doping prevention. Such cases became reason why legal regulations and all the forms of the practices against doping in sports should be analyzed and updated in a dynamic manner in order to ensure that the idea of rivalry is based on the timeless value which is fair play rule.

Currently basic definition of the doping in sport can be found in the Law of $21^{\text {st }}$ April 2017 against doping in sports that replaced legal provisions of the chapter 9, Law of $25^{\text {th }}$ June 2010 on sports ${ }^{9}$, The latest document (Law of $21^{\text {st }}$ April) defines it as the fact of discovering prohibited substances in a sample provided by the sportsman, refusal of providing with such a sample or unjustified non-appearance for the examination set up to take samples. Such a view results in the fact that legislator consider as doping also a situation when sportsman intentionally avoids undergoing examination for usage of prohibited substances or methods. In addition, it is not only actual fact of using prohibited substances but also attempt to use or going further, possession of mentioned substances or tools enabling player to benefit from a legally forbidden method ${ }^{10}$. According to the Article 3 paragraph 1 of the Law of $21^{\text {st }}$ April 2017 the legislator indicated that it is prohibited not to provide with the required data concerning place of residence of the player in order to perform doping check and to manipulate or attempt to manipulate any step of such an examination.

Another important aspect of the doping declared as prohibited is a situation commonly seen in the media. Sportsmen who is accused of doping and is trying to avoid the consequences claims not to be aware of any prohibited drugs found positive in dope test. Frequently such a statement is followed by the claim that the defendant has taken prohibited

\footnotetext{
7 Amended Anex n ${ }^{\circ} 1$ to the International Converntion Against Doping in Sports dated $19^{\text {th }}$ October 2005, Paris effective 1st January 2018 (Journal of Laws of 2018, item 40).

8 Art. 2 of The Law of $21^{\text {st }}$ April 2017 against Doping (Journal of Laws 2017, item 1051).

9 Law of $25^{\text {th }}$ June 2010 on sports (Journal of Laws of 2018 r., item 1263).

10 Art. 3 of Law of $21^{\text {st }}$ April 2017 against doping control, (Journal of Laws. of 2017., item. 1051).
} 
substance unintentionally, following recommendation of one of the team's members ex., trainer, doctor or physiotherapist.

Much attention has been focused on the case from 2016 when prominent cross-country skier Therese Johaug was tested positive to use prohibited substance (clostebol). In this case, it was the team's doctor who took the responsibility and explained the situation as an oversight from his side ${ }^{11}$. In spite of that fact, Johaug was severely punished - she was disqualified for 18 months and returned to the competitions in April 2018 ${ }^{12}$. interpreting Article 3 paragraph 1 subparagraph 8 of the Law of $21^{\text {st }}$ April 2017 defining doping in sport as delivering or attempt to deliver banned substance or method regardless it happens during the competition or outside of that time, it needs to be admitted that such a decision of the legislator limits the possibilities of repeating such circumstances and implicitly oblige athletes to keep special vigilance. Furthermore, it was declared that acts such as aiding and incitement and also all kind of conscious cooperation, that can be related to the act considered as doping in sport is strictly legally seen as doping in sport. The reasoning behind this approach is to discourage other individuals to persuade or provide with banned substances or use prohibited method on an athlete regardless it happens consciously or unconsciously. To sum up discussed topic, the role played by the athlete in process of enhancing performance by using prohibited methods is irrelevant whenever he is tested positive for the dope test $^{13}$.

Polish law, according to the international standards, allows to possess and use by the athletes commonly banned substances and methods and to administer them during and outside of competition as long as it is dictated by the curative reasons. It is rare and very detailed in its procedure practice, caused by the sportsman's health related issues, that still does not definitively prevent from playing sports at the highest professional level. Whenever this kind of situation happens, each case is reviewed in a professional and individual manner. It is related to the fact that health problems can be generally divided into two groups. Those that concerns our private life and the ingrediencies used in prescribed drugs are listed as substances prohibited in sports. The other group represents the substances that directly do not allow effective competition within a particular sports discipline. In such cases lawgiver decided that the derogation is named exclusion for therapeutic purposes ${ }^{14}$. In order to be granted an exclusion there need to be fulfilled four basic criteria. An athlete is obliged to demonstrate that the banned substance or method is necessary to treat chronic medical condition which could cause significant damage to health in case the treatment using prohibited drug is discontinued and at the same time following forbidden method or taking substance has no significant impact on improvement of the performance in comparison to the results achieved by a player after recovery resulted of termination of the treatment ${ }^{15}$. Another condition to be granted described exclusion requires that the originally banned substance or method does not allow any alternative therapeutic treatment, whereas the necessity of applying the treatment by using prohibited substance or method does not

\footnotetext{
${ }^{11}$ https://sportowefakty.wp.pl/biegi-narciarskie/637224/therese-johaug-zlapana-na-dopingu (accessed on 10.11.2018).

12 https://sportowefakty.wp.pl/biegi-narciarskie/769288/therese-johaug-wrocila-do-rywalizacji-juzjest-najlepsza (accessed on 10.11.2018).

13 Edit. M. Leciak, Leksykon prawa sportowego, publ. C.H.Beck, Warsaw 2017, p. 27.

${ }_{14}$ Annex $^{\mathrm{o}} 2$ to the International Convention Against Doping in Sports dated 1st January 2015, Paris.

${ }^{15}$ Annex $\mathrm{n}^{\circ} 2$ to the International Convention ..., Art. 4.1, par. a and b.
} 
come from the fact of using (without permission to exclude for therapeutic purposes) substance or method that was banned at the time of usage ${ }^{16}$. In this place author should mention that Annex 2 of the cited International Convention Against Doping in Sport in article 4.3 allows to apply for permission to use banned substance or method for therapeutic purposes with retroactive effect. The exception of such nature exist extremely rarely and mostly under very particular circumstances, when it is necessary to take immediate action in order to treat certain illness.

All the regulations that have been presented and analyzed in this chapter shall be recognized as highly rational and ensuring dual aspect of guarantees of security in sport by its flexibility. On the one hand, from legislative perspective they stand guard over the universal idea permanently linked with sport which is fair play. On the other hand, these regulations enable continuous competition for athletes who despite their medial issues can professionally plays sports de iure using medicaments including prohibited substances according to the exclusion for therapeutic purposes.

\section{POLISH ANTI-DOPING AGENCY AS AN INSTITUTION APPOINTED TO FIGHT AGAINST DOPING IN SPORTS}

Polish Anti-Doping Agency (POLADA) as a state legal person is in fact a new organization established under the Law of $21^{\text {st }}$ April 2017 concerning doping control. Since 1 st July 2017 POLADA plays role of polish national organization against doping. It has replaced and taken over responsibilities and competencies of the previous body, Commission Against Doping in Sports ${ }^{17}$. Its supervision and granting the statut falls within competence of minister with the responsibility for physical culture ${ }^{18}$, while it is financed mainly from the subsidies from the state budget ${ }^{19}$. Additional sources of financing may come also through the assets coming from European Union budget, revenues from commercial activities, inheritances and donations ${ }^{20}$.

It should be noted that apart from the indicated Law of 21 $1^{\text {st }}$ April 2017 against doping, there is number of other basic enactments that are merits-related complementing provisions of the Law and their content regulates in details POLADA's rights and obligations. The first one is Polish Anti-Doping Agency organizational rules dated 1st July $2017^{21}$. The document states i.e. that the management body of POLADA is the Director. According to the Article 4 paragraph 1 of the organizational rules it has to be admitted that this position has been granted with broad powers to define POLADA human resources policies, to play a role of representant of the organization. In addition, Director is obliged i.e. to prepare:

- draft of annual financial plan,

- annual report on its execution,

- plan of annual and long-term action plan.

\footnotetext{
${ }^{16}$ Annex $\mathrm{n}^{\mathrm{o}} 2$ to the International Convention ..., Art 4.1, par. $\mathrm{c}$ and $\mathrm{d}$.

17 D. Błachnio, M. Rynkowski, Polski system antydopingowy [in:] M. Rynkowski, Antydoping w Polsce, Warsaw 2014, p. 31-32.

18 Art. 4 Law of 21st April 2017.

19 Art. 30 par. 1 Law of 21 st April 2017.

20 Art. 30 par. 2 Law of 21 st April 2017.

21 Annex to the Decision $n^{\circ} 1$ of Director of Polish Anti-Doping Agency dated $1^{\text {st }}$ July 2017.
} 
To complete the picture, it should be noted that there has also been established Council of Polish Anti-Doping Agency whose procedures and principles are described in the Law of $21^{\text {st }}$ April against doping, statute of POLADA and organizational rules for Council of Agency. It has advisory character against the works of Polish Anti-Doping Agency ${ }^{22}$. Moreover, according to the paragraph 8 of the organizational rules, POLADA consist of following departments: Secretary, Department of Information and Education, Department of Administration and Finance, Department for Doping Control and Performance Management to finish with Analytics and Investigation Group. Each department has their individual, highly specialized responsibilities, which are described in paragraphs 29 to 33 of the POLADA's organizational rules. Such a split enables full professionalism of the tasks assigned to the individual groups and in consequence, it allows to enhance efficiency of POLADA.

Another legislative act that complements the Law of $21^{\text {st }}$ April against doping at the substantive level are Anti-Doping Control and Test Results Management Regulations ${ }^{23}$. Already paragraph 1 of the normative document define its basic guidelines. A significant role in the Agency's role take anti-doping controls, that may be performed during and in between of the competitions - it often concerns such a time like training camps, consultations or simply regular trainings. The control itself bases on extracting samples and evidences provided that individuals who are subject to the control are not informed in advance that the examination will take place. What is interesting, an athlete who has set a new Poland, Europe or World record and has not been tested for doping is obliged to contact Polish AntiDoping Agency in order to perform such a test. Additionally, the examination needs to be done during the competiion and according to the applicable procedures and it should be completed within 24 hours from the time of setting the record. In the reminder of AntiDoping Control and Test Results Management Regulations there are basic instructions concerning planning, execution, data and results analysis related to the doping control and the procedures concerning reporting violation of the anti-doping regulations. The paragraph 4 includes information concerning structure and the range of the rights and obligations so called controlling groups. The solutions accepted through the organizational rules make a procedure related to the doping control fully transparent and easy to understand, which are key matters in terms of law execution by the national and international organs.

Another normative act which is subject to the analysis regulates operation of the institution responsible for ruling in cases concerning violations of the anti-doping regulations. This is Anti-Doping Disciplinary Panel within the Polish Anti-Doping Agency. The fact that should be highlighted is that it has jurisdiction both in the first and second instances ${ }^{24}$. This means that Disciplinary Panel is independent from POLADA's organs and it is led by a president. In this kind of legal proceedings the role of prosecutor devolve on Polish AntiDoping Agency, whereas the other party is defendant who apart form personal attendance may in the course of the proceedings appoint no more than three representatives. Further regulations of the Polish Anti-Doping Agency organizational rules provide with the complex information concerning course of proceeding and also costs related to its execution.

${ }^{22}$ M. Leciak (edit.), M. Biliński, K. Grabska-Luberadzka, R. Piechota, H. Radke, B. Rischka-Słowik, K. Tetłak, Prawo sportowe, Warsaw 2018, p. 374-375.

${ }^{23}$ Annex to the Decision n ${ }^{\circ} 4$ of Director of Polish Anti-Doping Agency dated 1st July 2017.

24 Art. 1 par. 3 Regulations Anti-Doping Disciplinary Panel within the Polish Anti-Doping Agency dated 13th July 2017. 
Finally, the last of the acts that constitute integral part of the previously described documents is the largest one in terms of content, these are Anti-doping regulations of the Polish Anti-Doping Agency dated $1^{\text {st }}$ July, 2017. It was redacted based on World Anti-Doping Code (WADC) accepted by Foundation Board of World Anti-Doping Agency (WADA) in 2015. It is worth mentioning that WADA was established on 10th November 1999 and it functions as a foundation. In order to fulfill its main task, which is acting against doping, WADA coordinates various activities on an international level, mainly by as efficient as possible unification of the variety of anti-doping regulations existing currently in sports ${ }^{25}$. To underline even further how important role is played by WADA, it should be noted that unification and harmonization of international anti-doping regulations allows to ensure widely understood safety and security in that matter ${ }^{26}$. What is interesting, World AntiDoping Agency is a private entity what initially was arising controversies. Over the time and as a result of intense efforts to build the trust and position in the international arena, WADA became a fully respected unit who leads anti-doping actions at the international level. Such a crucial moment was taking into effect in 2004 WADC who replaced Olympic Movement Code on the Prevention of Doping at the start of The 2004 Summer Olympic Games held in Athens ${ }^{27}$.

A closer insight into the international background, described in details in a previous paragraph plays a key role in an analysis of the norms of the Regulations of Polish AntiDoping Agency. The ownership law regulates in a complex and detailed manner i.e. following matters. Definition of the idea of doping in sports, proceeding with doping tests, setting the penalties that individual athletes and whole teams that they represent are liable to, and information concerning the fact that POLADA is responsible for planning, implementation and monitoring of educational programs, whose role is to make society aware of the dangers brought by the existence of doping in sports ${ }^{28}$.

Unfortunately, despite the number of educational programs prepared by International and Polish Anti-Doping Agency the athletes tested positive for doping often excuse themselves with unawareness of their actions. Unfortunately, such explanation is not taken into account. This approach comes from the one of the basic rules of the law, which is ignorantia iuris nocet, ignorance of the law is harmful. For the sake of convenience it should be noted that regulations of Polish Anti-Doping Agency are enactments that cover most of the major issues related to the doping because they are described in a consistent and system way what prevents from future excuses based on the fact that one's has not been aware of the nature of his actions at the time of using prohibited substance or method.

\section{CONCLUSION}

The actions against doping is a tough and at the same time one of the most important responsibilities that rest on the international and state authorities specializing in this matter. The idea of doping in sports is connected by the society with testing an athlete positive as

\footnotetext{
${ }^{25}$ E.J. Krześniak, Kluby i organizacje sportowe w prawie polskim na tle rozwiazań zagranicznych, Warsaw 2016, p. 99.

${ }^{26}$ S. Fundowicz, Prawo sportowe, Warsaw 2013, p. 227.

27 R. Piechota, Reguty antydopingowe w prawie międzynarodowym, Studia Iuridica Toruniensia tom VI, publ. Uniwersytet Mikołaja Kopernika w Toruniu, Toruń 2010, p. 165.

${ }^{28}$ Regulations of Polish Anti-Doping Agency version 2.1, dated 1st July 2017.
} 
a part of competition. It should be noted though that professional sportsman who is actively playing sports is legally obliged to obey the regulations against doping.

It is important to highlight the consequences of such practices, not only legal but also moral and health related that are borne by the player who uses prohibited substances or banned methods. It opposes the idea of ensuring broadly understood safety and security in sport because it is not only form of dishonest practice. Another negative aspect is breaking the essential principle leading this sphere of life, which is fair play. Furthermore, the athletes who use prohibited doping often are not aware of the possible side effects on health, which might be revealed in a future.

Polish Anti-Doping Agency established pursuant to the Law of $21^{\text {st }}$ April against doping in sport bears responsibility for ensuring that sport is free from the dopes. POLADA hold all the legal and administrative tools that let assume that the challenging task will be completed in an efficient manner. As a matter of opinion, the most spectacular case of testing positive a sportsman for the usage of dopes, that falls within the jurisdiction of recently established Polish Anti-Doping Agency was case of Grigorij Łaguta, speedway rider of ROW Rybnik Team. Based on the doping control performed $11^{\text {th }}$ June 2016 after the race of the top division of motorcycle speedway in Poland between the teams of ROW Rybnik Włókniarz Vitroszlif CrossFit Częstochowa Grigorij Łaguta was found to use the substance prohibited since 2016 - meldonium ${ }^{29}$. Anti-doping Disciplinary Panel within the Polish Anti-Doping Agency proclaimed in the first instance penalty of 2 years suspension. However, the penalty has been reduced to 21 months as part of proceedings in the second instance. This ruling was based on the principle of proportionality and resulted directly from the fact that thanks to such decision rider will be able to start in the season of 2019, which would be impossible due to the closed transfer window in the case of maintaining the original penalty issued for 24 months ${ }^{30}$. Such a ruling should be evaluated in a positive way, because the penalty for doping in sport still remains severe, but at the same time does not prevent from development of the career of such an prominent speedway rider as Grigory Łaguta.

In addition, it is to be hoped that in the future doping in sport will be less and less frequent, and in order to achieve this goal both the Polish Anti-Doping Agency and its international counterpart should put even more emphasis on preventive actions based on organizing and publishing informational and educative materials, which will ultimately maximize safety and security in sport.

\section{REFERENCES}

\section{LEGAL ACTS}

1. Law of 25th June 2010 on sports (Journal of Laws of 2018 r., item 1263).

2. The Law of 21st April 2017 against Doping (Journal of Laws 2017, item 1051).

\footnotetext{
${ }^{29}$ https://sportowefakty.wp.pl/zuzel/697720/grigorij-laguta-zlapany-na-dopingu (accessed on 10.11.2018).

${ }^{30}$ https://www.rybnik.com.pl/wiadomosci,kara-dla-grigorija-laguty-skrocona-o-3-miesiace, wia5-3270-35890.html (accessed 10.11.2018).
} 
3. International Convention Against Doping in Sports dated 19th October 2005 (Journal of Laws of 2007, item 999, Journal of Laws of 2013, item 1243, Journal of Laws of 2014, item 343, Journal of Laws of 2016, item 79.

4. Amended Anex $n^{\circ} 1$ to the International Converntion Against Doping in Sports dated 19th October 2005, Paris effective 1st January 2018 (Journal of Laws of 2018, item 40).

5. Annex $n^{\circ} 2$ to the International Convention Against Doping in Sports dated 1st January 2015, Paris.

6. Annex to the Decision $n^{\circ} 1$ of Director of Polish Anti-Doping Agency dated 1st July 2017.

7. Annex to the Decision $n^{\circ} 4$ of Director of Polish Anti-Doping Agency dated 1st July 2017.

8. Regulations of Anti-Doping Disciplinary Panel within the Polish Anti-Doping Agency dated 13th July 2017.

9. Regulations of Polish Anti-Doping Agency version 2.1, dated 1st July 2017.

\section{LITERATURES}

1. Błachnio D., M. Rynkowski, Polski system antydopingowy [w:] M. Rynkowski, Antydoping w Polsce, wyd. Komisja do Zwalczania Dopingu w Sporcie, Warszawa 2014.

2. Fundowicz S., Prawo sportowe, Wolters Kluwer, Warszawa 2013.

3. Krześniak E. J., Kluby i organizacje sportowe w prawie polskim na tle rozwiąań zagranicznych, Wolters Kluwer, Warszawa 2016.

4. Leciak M. (red.), Leksykon prawa sportowego, C.H. Beck, Warszawa 2017.

5. M. Leciak (red.), M. Biliński, K. Grabska-Luberadzka, R. Piechota, H. Radke, B. Rischka-Słowik, K. Tetłak, Prawo sportowe, C.H. Beck, Warszawa 2018.

6. Leszczyńska A., Szprycujący się koksiarze przyłapani na dopingu. Obraz zjawiska dopingu $w$ sporcie w polskiej prasie na przyktadzie tekstów $z$, Gazety Wyborczej” $i$ „,Przeglądu Sportowego" [w:] M. Jarosz, P. Drzewiecki, P. Płatek, Sport w mediach, Dom Wydawniczy ELIPSA, Warszawa 2013.

7. Pasik M., D. Kwiatkowska, A. Pokrywka, Doping w sporcie i doping oczami mediów-próba charakterystyki zjawiska [w:] M. Jarosz, P. Drzewiecki, P. Płatek, Sport w mediach, Dom Wydawniczy ELIPSA, Warszawa 2013.

8. Piechota R., Reguty antydopingowe w prawie międzynarodowym, Studia Iuridica Toruniensia tom VI, wyd. Uniwersytet Mikołaja Kopernika w Toruniu, Toruń 2010.

9. Zawartka M., Zagrożenia dla bezpieczeństwa w sporcie, [w:] M. Bednarczyk, K. Nessel, Przedsiębiorczość w sporcie zasady i praktyka, wyd. CeDeWu, Warszawa 2016.

\section{INTERNET SOURCES}

1. https://sportowefakty.wp.pl/biegi-narciarskie/637224/therese-johaug-zlapana-na-dopingu

2. https://sportowefakty.wp.pl/biegi-narciarskie/769288/therese-johaug-wrocila-do-rywalizacji-juz-jest-najlepsza

3. https://sportowefakty.wp.pl/zuzel/697720/grigorij-laguta-zlapany-na-dopingu;

4. https://www.rybnik.com.pl/wiadomosci,kara-dla-grigorija-laguty-skrocona-o-3-miesiace, wia5-3270-35890.html 


\title{
ANALIZA ORAZ OCENA WYBRANYCH ASPEKTÓW WALKI Z DOPINGIEM W SPORCIE JAKO ZADANIE ORGANÓW PAŃSTWOWYCH W CELU ZAPEWNIENIA BEZPIECZEŃSTWA W SPORCIE
}

\begin{abstract}
W artykule przeprowadzona została analiza i ocena przyjętych, na podstawie ogólnoświatowych standardów, regulacji prawno-organizacyjnych podmiotów specjalizujących się w przeciwdziałaniu nielegalnego zjawisku dopingu w sporcie. Szczególna uwaga została poświęcona powołanej do życia w 2017 roku na mocy ustawy o zwalczaniu dopingu w sporcie Polskiej Agencji Antydopingowej (POLADA), której kompleksowe zasady funkcjonowania określone zostały w kilku odrębnych aktach prawnych. Rozważania zostały poparte przykładami najgłośniejszych afer dopingowych ostatnich lat zarówno na świecie, jak i w Polsce. Autor ocenia, iż obecnie obowiązujące regulacje prawne, a także ich praktyczne zastosowanie, co do zasady pozwalają na efektywne przeciwdziałanie podmiotom stosującym lub rozpowszechniającym środki lub metody ustawowo zabronione. Przepisy prawne, a co za tym idzie - działalność takich instytucji jak Polska Agencja Antydopingowa muszą ulegać ciągłej ewaluacji, tak aby móc reagować na coraz to nowsze próby stosowania niedozwolonego dopingu w sporcie, ponieważ ma to bezpośredni wpływ na zagwarantowanie szeroko pojętego bezpieczeństwa w sporcie.

Ponadto autor wskazuje, iż jedną z najlepszych metod walki z dopingiem jest ukazywanie możliwych negatywnych skutków jakie wywołuje. Stąd też powinny być inicjowane i propagowane w społeczeństwie kolejne programy edukacyjne, a także informacyjne na ten temat, gdyż zjawisko stosowania przez profesjonalnych sportowców środków i metod zabronionych stoi w sprzeczności z fundamentalną regułą, na której powinna opierać się rywalizacja sportowa, a mianowicie zasadzie fair play. Dodatkowymi konsekwencjami w przyszłości mogą być również poważne problemy zdrowotne u osób stosujących doping w trakcie trwania ich karier sportowych.
\end{abstract}

Słowa kluczowe: doping w sporcie, Polska Agencja Antydopingowa, środki zabronione, metody zabronione.

DOI: $10.7862 /$ rz.2018.mmr.50

Tekst ztożono do redakcji: listopad 2018 r.

Tekst przyjęto do druku: grudzień 2018 r. 